\title{
Glutathione, glutathione peroxidase and some hematological parameters of HIV- seropositive subjects attending clinic in University of Calabar teaching hospital, Calabar, Nigeria
}

Stephen Bassey Coco-Bassey ${ }^{1}$, Enosakhare A. Asemota ${ }^{2}$, Henshaw Uchechi Okoroiwu ${ }^{2 *}$ (D, Joyce E. Etura ${ }^{2}$, Esienanwan Esien Efiong ${ }^{3}$, Imeobong J. Inyang ${ }^{2}$ and Emmanuel K. Uko ${ }^{2}$

\begin{abstract}
Background: Despite the numerous intervention programmes, HIV still remains a public health concern with a high impact in Sub-Saharan Africa region. Oxidative stress has been documented in HIV subjects as viral infection promotes prolonged activation of immune system, hence, production of increased reactive oxygen species.

Methods: We studied 180 subjects. Of these, 60 were HIV-infected on antiretroviral therapy (ART), 40 were ART naïve HIV-infected and 80 were apparent healthy non HIV-infected subjects. The complete blood count was performed by automated hemoanalyzer, the $\mathrm{CD}^{+}{ }^{+} \mathrm{T}$-cell count was performed by cyflow cytometer, while the antioxidant assay was performed using ELISA technique.
\end{abstract}

Result: All evaluated parameters; glutathione (GSH), glutathione peroxidase (GPX), CD4 ${ }^{+}$T-cell count, haemoglobin $(\mathrm{Hb})$, total white blood cell count (WBC) and platelet count were significantly $(P<0.05)$ reduced in the HIV-infected subjects. All assessed parameters were found to be significantly $(P<0.5)$ reduced in the HIV-infected subjects that are ART naive when compared with those on ART. HIV-infected subjects with CD4 ${ }^{+}$T-cell count $<200 \mathrm{cell} / \mathrm{s} / \mathrm{mm}^{3}$ had significantly $(P<0.05)$ reduced values in all assessed parameters when compared to those with $\mathrm{CD} 4^{+} \mathrm{T}$-cell count $\geq 200$ cells $/ \mathrm{mm}^{3}$. GSH and WBC were found to be significantly $(P<0.05)$ increased in the female HIV-infected subjects when compared with the male counterpart. Anemia prevalence of 74 and 33\% were recorded for the HIVinfected and control subjects, respectively. Gender and ART treatment were found to be associated with anemia in HIV. Male HIV-infected subjects on ART were found to be more likely to have anemia.

Conclusion: Antioxidants; GSH and GPX were found to be significantly reduced in HIV infection. Further probe showed that the antioxidant status was improved in the HIV-infected group on ART.

Keywords: Antioxidants, Glutathione, Glutathione peroxidase, HIV, Calabar

\footnotetext{
* Correspondence: okoroiwuhenshaw@gmail.com

${ }^{2}$ Haematology Unit, Department of Medical Laboratory Science, University of

Calabar, Calabar, Nigeria

Full list of author information is available at the end of the article
}

(c) The Author(s). 2019 Open Access This article is distributed under the terms of the Creative Commons Attribution 4.0 International License (http://creativecommons.org/licenses/by/4.0/), which permits unrestricted use, distribution, and reproduction in any medium, provided you give appropriate credit to the original author(s) and the source, provide a link to the Creative Commons license, and indicate if changes were made. The Creative Commons Public Domain Dedication waiver (http://creativecommons.org/publicdomain/zero/1.0/) applies to the data made available in this article, unless otherwise stated. 


\section{Background}

There are about 36.7 million persons living with HIV as at the end of 2016. World Health Organization report estimated approximately $0.8 \%$ of adults within the age bracket of 15-45 years globally are living with HIV. Though HIV epidemic varies per region, the subSaharan region maintains the highest incidence such that approximately 1 in every 25 adults (4.2\%) is infected by HIV giving rise to almost two-third of the population of those living with HIV globally [1, 2]. Despite the advance in virological and clinical management, HIV infection has developed into a worldwide pandemic [3]. Infection with Human Immune Deficiency Virus (HIV) is associated with progressive loss of cellular immunity which results to life-threatening opportunistic infections and progressive development of Acquired Immune Deficiency Syndrome [4]. Of all the people living with HIV globally, 9\% of them live in Nigeria according to 2014 Gap report [5]. There were 3.2 million people living with HIV in Nigeria in 2016, among whom 30\% were assessing antiretroviral treatment or prophylaxis to prevent transmission to their children [6]. Hence, Nigeria is now the second largest HIV disease burden in the world after South Africa which has 7.1 million (19\% of global epidemic) burden of the disease, though prevalence is stable at $3.4 \%$ [7, 8]. By states, HIV prevalence in Nigeria varies. The highest number of HIV prevalence were recorded in Benue, Anambra, Bayelsa and Akwa Ibom States of the federation and the Federal Capital territory (FCT) with prevalence greater than $8 \%$. The least HIV prevalence areas are Kebbi, Ekiti, Katsina, Jigawa and Bauchi States of the federation with prevalence range of $1-2 \%[8]$.

In 2016, Nigeria established its guideline for ART treatment [9]. However, the World Health Organization (WHO) recommendation of ART for low and middle income countries is viz.: First line ART includes 2NRTIs ( 1 of TDF, AZT, ABC +1 of 3TC, FTC) +1 NNRTI (NVP or EFV) with specific recommendations for patients aged 3-10 years and patients with impaired renal function. Second line ART includes 2NRTIs (1 of TDF, $\mathrm{AZT}, \mathrm{ABC}+1$ of $3 \mathrm{TC}, \mathrm{FTC})+1 \mathrm{PI} / \mathrm{r}(\mathrm{LPV} / \mathrm{r}, \mathrm{ATV} / \mathrm{r})$ with specific recommendation for children below 3 . Third line includes $1-2$ NRTIs + DRV/r + 1 INI (DTG or RAL) with specific recommendations for children below 10 and pregnant women [10].

There have been wide documentation of oxidative stress in persons living with HIV infection as the infection encourages long term activation of the immune system that eventually contribute to increased production of reactive oxygen species [11-14]. Oxidative stress results from an imbalance between formation and neutralization of pro-oxidants [15]. Several lines of evidence suggest that enhanced oxidative stress also plays a pathogenic role in human immunodeficiency virus (HIV) infection [15-17]. Increase in oxidative stress may accelerate disease progression, increasing HIV replication through signalling of nuclear factor (NF)-KB as well as mutation rate of the viral RNA genome, leading to greater damage to the host $[13,14]$.

There are several enzymatic cum non-enzymatic antioxidants in cells that prevent or in some cases cushion damages associated with reactive oxygen species [18]. The immune system consists of many compound with varying properties: macromolecules such as albumin and ceruloplasmin; enzymes such as glutathione peroxidase, superoxide dismutase, catalase; and small molecules such as reduced glutathione, vitamin $C$, vitamin $E$, uric acid, and $\beta$-Carotene [19]. Glutathione is documented as the most copious non-protein thiol in living organisms and plays many relevant biological roles among which are: $\mathrm{T}$ and $\mathrm{B}$ cell differentiation, cell defense and cytotoxic T-cell activation. More so, it plays antioxidant role scavenging reactive oxygen species and limiting hydrogen peroxide [20]. Glutathione is a tripeptide consisting of cysteine REPLACE WITH: (L- $\gamma$-glutamyl-L-cysteinylglycine) that is present in minute (millimolar) quantity in all animal cells [21]. De novo, Glutathione (GSH) is produced from the tripeptide consisting of glycine, amino glutamine and cysteine. Glutathione occurs in two forms intracellularly; the oxidized form (GSSG) and the reduced form (rGSH). There are basically two steps involved in the formation of the rGSH which involves two enzymes; glutamate-cysteine ligase (GCL) and glutathione synthase (GSS). The first as well as the rate limiting step reaction involving the synthesis of $\mathrm{GSH}$ is catalysed by GCL. GCL is composed of catalytic (GCLC) and a modifier (GCLM) subunit [22, 23]. An alternative pathway is the reconversion of GSSG back to GSH in the presence of the enzyme glutathione reductase (GSR) using NADPH as cofactor [22].

This study is aimed at investigating the antioxidant status of HIV positive subjects with the view of providing information on improving the management of HIV patients.

\section{Method \\ Study designs and subjects}

A total of one hundred and eighty (180) subjects were recruited for this study. Sixty (60) of these were HIVinfected subjects on antiretroviral therapy (ART), while 40 were HIV-infected ART naive subjects. Eighty (80) apparently healthy HIV negative subjects were recruited as control. The HIV infected subjects were attending University of Calabar Teaching Hospital HIV Clinic. All subjects were drawn from both gender and aged between 18 and 60 years and were all resident in Calabar, Nigeria. Ethical approval was obtained from Health 
Research Ethical Committee (HREC) of the University of Calabar Teaching Hospital. Informed consent was obtained from the subjects involved in this study. Pregnant women, tuberculosis patients and those currently undergoing treatment for any chronic illness were excluded from the study. The study took place from March to April, 2016. The ART combination given to patients at the study area as at the time of study are combination of two nucleotide reverse transcriptase inhibitors and one non-nucleotide reverse transcriptase inhibitor (Tenofovir+Lamivudine+Efavirenz or Lamivudine+Zidovudine+Nevirapine). All sample assays were performed in duplicate and the average values recorded.

\section{Sample collection}

Six milliliter $(6 \mathrm{~mL})$ of venous blood was collected from the subjects. Two Milliliter $(2 \mathrm{~mL})$ of the collected blood was dispensed into plain tube for serum harvesting for glutathione and glutathione peroxidase and the remaining $4 \mathrm{~mL}$ was dispensed into dipotassium ethylene diamine tetra - acetic acid $\left(\mathrm{K}_{2} \mathrm{EDTA}\right)$ container for complete blood count and $\mathrm{CD}^{+}{ }^{+} \mathrm{T}$-Cell count. The $\mathrm{CD} 4^{+} \mathrm{T}$-cell count and complete blood count were analyzed immediately while the sera for antioxidant analysis were frozen at $-20^{\circ} \mathrm{C}$ and analyzed within 1 week.

\section{Complete blood count and $\mathrm{CD} 4^{+} \mathrm{T}$-cell assay}

The $\mathrm{CD}^{+}{ }^{+} \mathrm{T}$-cell count was performed using Partex Cyflow cytometer by Partec cyflow, Germany. Following the booting of the machine, $20 \mu \mathrm{L}$ of $\mathrm{CD}^{+}{ }^{+} \mathrm{T}$-cell count phycoerythrin monoclonal antibody (PEmAb) was added to a Rohren tube and subsequently by $20 \mu \mathrm{L}$ of well mixed EDTA anticoagulated blood sample. The mixture was mixed and incubated in the dark for $15 \mathrm{~min}$ at room temperature. Next, $800 \mu \mathrm{L}$ of the $\mathrm{CD} 4^{+}$T-cell count buffer was added. The final mixture was then mixed, plugged in the sample port, and read via the cyflow. Sysmex KX-21 N by Sysmex Corporation Kobe, Japan, was used in analysis of complete blood count. This was done following the manufacturer's instructions.

\section{Antioxidant assay}

The glutathione assay was performed using ELISA test kits from USCN Life Science, USA. The assay technique uses the competitive inhibition enzyme immunoassay principle in which monoclonal antibody specific to glutathione has been pre-coated onto a microplate and a competitive inhibition reaction launched between biotin labeled GSH and unlabeled GSH with the pre-coated antibody specific to GSH. Following incubation, the unbound conjugate was washed off and avidin conjugated to Horseradish peroxidase (HRP) added to each microplate well and incubated. The amount of bound HRP conjugate is inversely proportional to the concentration of glutathione present in the sample. The change is measured spectrophotometrically at $450 \mathrm{~nm} \pm 10 \mathrm{~nm}$.

The glutathione peroxidase (GPX) activity was performed using ELISA kits from USCN Life Science, USA. A monoclonal antibody specific to GPX (glutathione peroxidase 1) was pre-coated on the microplate. Avidin conjugated to Horseradish peroxidase (HRP) was then added to each microplate well and incubated after tetramethylbenzydine (TMB): substrate solution was added to only those well that contain GPX, biotin-conjugated antibody and enzyme-conjugated avidin will exhibit a change in colour. The enzyme-substrate reaction was terminated using the stop solution (sulphoric acid solution) and the change is measured spectrometrically at a wavelength of $450 \mathrm{~nm} \pm 10 \mathrm{~nm}$.

\section{Statistical analysis}

Data were analyzed using SPSS version 20 (SPSS Inc., Chicago, USA). Categorical data were represented with frequency and percentages while continuous data were expressed as mean and standard deviations. One sample Kolmogorov-Smirnov test was used to assess the normality of the data. All data were normally distributed, hence, parametric procedure was used. Comparison of the antioxidant variable and complete blood count between the test and control were performed using independent $\mathrm{t}$-test while comparison among various age groups were analyzed using ANOVA. Association between variables were analyzed using Chi Square and Fischer exact test. Risk estimates were analysed using odd ratio. Alpha value of 0.5 was used.

\section{Result}

The average age of the HIV-infected subjects in this study was $40.02 \pm 1.23$ years while that of the control was $35.04 \pm 1.19$ years. Forty six percent $(46 \% ; n=46)$ and $37.5 \%(n=30)$ of the HIV-infected subjects and the controls, respectively, were males while $54 \%(n=54)$ and $62.50 \%(n=50)$ of the HIV-infected subjects and controls, respectively, were females. Sixty percent $(60 \% ; n=$ 60) of the HIV-infected subjects were on ART while $40 \%$ were ART naïve. Nine percent $(9 \% ; n=9)$ of the HIV-infected subject had $\mathrm{CD}^{+}{ }^{+}$T-Cell count of $<200$ cells $/ \mathrm{mm}^{3}$. Of the $100 \mathrm{HIV}$-infected subject, $74 \%(n=$ 74) were anemic as against the $41.25 \%(n=33)$ anemia seen in the control subjects using World Health Organization (WHO) cut-off of $12 \mathrm{~g} / \mathrm{dL}$ and $13 \mathrm{~g} / \mathrm{dL}$ for females and males, respectively [24] (Table 1).

The highest prevalence of anemia among the HIVinfected subjects was observed in the males (84.74\%; 39/46) when compared with the female $(64.81 \% ; 35 / 54)$. Gender was significantly $(P<0.05)$ associated with anemia in HIV infection with an odd ratio (OR) of 1.958:1 (Male: Female $[\mathrm{CI}=1.003-3.822)$. The ART naïve HIV-infected subjects 
Table 1 Demographic and clinical data of the HIV infected subjects and healthy control

\begin{tabular}{lll}
\hline Parameter & $\begin{array}{l}\text { HIV Subjects } \\
N=100\end{array}$ & $\begin{array}{l}\text { Control } \\
N=80\end{array}$ \\
\hline AGE & $40.02 \pm 1.23^{\mathrm{a}}$ & $35.04 \pm 1.19^{\mathrm{a}}$ \\
GENDER & & \\
$\quad$ Male & $46(46.00)$ & $30(37.50)$ \\
$\quad$ Female & $54(54.00)$ & $50(62.50)$ \\
$\quad$ HIV SUBJECTS ON ART & $60(60.00)$ & \\
$\quad$ ART Naïve HIV SUBJECTS & $40(40.00)$ & \\
CD4 ${ }^{+}$T-CELL COUNT GROUP & & $0(0.00)$ \\
$\quad<200$ cells/mm ${ }^{3}$ & $9(9.00)$ & $100(100.00)$ \\
$\quad \geq 200$ cells/mm ${ }^{3}$ & $91(91.00)$ & $33(41.25)^{b}$ \\
$\quad$ ANEMIA PREVALENCE & $74(74.00)^{\mathrm{b}}$ & \\
\hline amean + S.D &
\end{tabular}

had higher $(90 \%$; 36/40) prevalence of anemia when compared to the HIV-infected subjects on ART (63.33\%; 38/ 60). ART status was significantly $(P<0.05)$ associated with anemia inn HIV infection with an OR of 0.607:1 (On ART: ART naïve $[C I=0.461-0.800)$. further stratification based on gender showed that males on ART treatment are more likely to be anemic than the females $(\mathrm{OR}=2.026 ; \mathrm{CI}=$ $0.967-4.247)$. There was no significant gender disparity among ART naïve subjects $(P>0.05)$. A $100 \%$ anemia was observed in the category of HIV infected subjects with $\mathrm{CD}^{+}{ }^{+} \mathrm{T}$-Cell count of $<200$ cell $/ \mathrm{mm}^{3}$. CD4 $4^{+} \mathrm{T}$-Cell status was found not significantly $(P>0.05)$ associated with anemia in HIV infection (Table 2).
Table 3 shows antioxidant and some hematological parameters of HIV-infected subjects and the control subjects. All assessed parameters (GSH, GPX, $\mathrm{CD}^{+}{ }^{+}$-cell count, hemoglobin, total white blood cell count, and platelet count of the HIV-infected subject were found to be significantly $(P<0.05)$ reduced in the HIV-infected subjects when compared with the control subjects.

Table 4 shows the antioxidant and some hematological parameters of the HIV-infected subjects on antiretroviral therapy (ART) and ART-naïve group. All assessed parameters (GSH, GPX, CD4 $4^{+}$T-cell count, hemoglobin, total white blood cell count and platelet count were found to be significantly $(P<0.05)$ reduced in the ART naïve group when compared with those on ART therapy.

Table 5 shows the antioxidant and some hematological parameters of the HIV-infected subjects based on their CD4 category. All assessed parameters (GSH, GPX, $\mathrm{CD}^{+}{ }^{+} \mathrm{T}$-cell count, hemoglobin, total white blood cell count and platelet count were found to be significantly $(P<0.05)$ reduced in the $<200$ cells $/ \mathrm{mm}^{3}$ category when compared with the $>200$ cells $/ \mathrm{mm}^{3}$.

Table 6 shows the antioxidant and some hematological parameters of HIV-infected subjects based on gender. GPX, $\mathrm{CD}_{4}{ }^{+} \mathrm{T}$-cell count, hemoglobin, and platelet values were comparable $(P>0.05)$ in both gender. Only glutathione (GSH) and total white blood cell count were significantly reduced in the males when compared with the females.

Table 7 shows antioxidant and some hematological parameters of HIV-infected subjects on ART treatment based on duration of treatment. All the parameters (GSH, GPX, CD4 $4^{+}$T-cell count, hemoglobin, total white

Table 2 Variable associated with anemia in HIV

\begin{tabular}{|c|c|c|c|c|c|}
\hline Parameter & N. anemic (\%) & $x^{2}$ & $P$-value & Odd ratio & $95 \% \mathrm{Cl}$ \\
\hline \multicolumn{6}{|l|}{ GENDER } \\
\hline Male & 39 (84.78) & 5.14 & $0.023^{*}$ & 1.958 & $1.003-3.882$ \\
\hline Female & $35(64.81)$ & & & 1 & \\
\hline \multicolumn{6}{|l|}{ ART CATEGORY } \\
\hline On ART & $38(63.33)$ & 8.870 & $0.003^{*}$ & 0.607 & $0.461-0.800$ \\
\hline ART Naïve & $36(90.00)$ & & & 1 & \\
\hline \multicolumn{6}{|l|}{ On ART CATEGORY } \\
\hline Male & $21(77.78)$ & 4.411 & $0.036^{*}$ & 2.026 & $0.967-4.247$ \\
\hline Female & $17(51.52)$ & & & 1 & \\
\hline \multicolumn{6}{|l|}{ ART NAIIVE CATEGORY } \\
\hline Male & $18(94.74)$ & 0.902 & 0.342 & 2.000 & $0.355-11.265$ \\
\hline Female & $18(85.71)$ & & & 1 & \\
\hline \multicolumn{6}{|l|}{ CD4 CATEGORY } \\
\hline$<200$ cells $/ \mathrm{mm}^{3}$ & $9(100)$ & & $0.107^{\mathrm{a}}$ & 0.878 & $0.807-0.956$ \\
\hline$\geq 200$ cells $/ \mathrm{mm}^{3}$ & $65(71.43)$ & & & 1 & \\
\hline
\end{tabular}

${ }^{\mathrm{a}} p$ value for fisher exact test

$N$ absolute numbers; $H b$ hemoglobin, GSH glutathione, GPX glutathione peroxidase; $W B C$ b white blood cell count; $C D$ cluster of differentiation

*: Significantly different 
Table 3 Antioxidant and some hematological parameters of HIV-infected and control subjects

\begin{tabular}{|c|c|c|c|}
\hline \multirow[b]{2}{*}{ Parameter } & \multicolumn{3}{|l|}{ Subjects } \\
\hline & $\begin{array}{l}\text { HIV Subjects } \\
N=100 \\
\text { Mean } \pm \text { S.D. }\end{array}$ & $\begin{array}{l}\text { Control Subjects } \\
N=80 \\
\text { Mean } \pm \text { S.D }\end{array}$ & $p$-value \\
\hline \multicolumn{4}{|l|}{ ANTIOXIDANTS } \\
\hline $\mathrm{GSH}(\mu \mathrm{g} / \mathrm{mL})$ & $3.76 \pm 1.87$ & $6.00 \pm 2.94$ & $<0.01^{*}$ \\
\hline GPX (pg/mL) & $123.15 \pm 62.05$ & $228.17 \pm 80.04$ & $<0.01^{*}$ \\
\hline \multicolumn{4}{|l|}{ HEMATOLOGY } \\
\hline CD4 (cells $/ \mathrm{mm}^{3}$ ) & $414.23 \pm 236.24$ & $689.66 \pm 283.31$ & $<0.01^{*}$ \\
\hline $\mathrm{Hb}(\mathrm{g} / \mathrm{dl})$ & $11.27 \pm 1.84$ & $12.61 \pm 1.70$ & $<0.01^{*}$ \\
\hline WBC $\left(\times 10^{9} / L\right)$ & $3.69 \pm 1.04$ & $5.23 \pm 2.06$ & $<0.01^{*}$ \\
\hline Platelet $\left(\times 10^{9} / \mathrm{L}\right)$ & $177.83 \pm 62.13$ & $243.14+71.99$ & $<0.01^{*}$ \\
\hline
\end{tabular}

$\mathrm{N}$ absolute number; $\mathrm{Hb}$ hemoglobin; GSH glutathione

GPX glutathione peroxidase; WBC white blood cells count

$C D$ cluster of differentiation

*: Significantly different

blood cell count and platelets) assessed were comparable $(P>0.05)$ in all groups.

Table 8 shows antioxidant and some hematological parameter of HIV infected subjects based on age. The values of all parameters assessed (GSH, GPX, CD4 ${ }^{+}$T-cell count, haemoglobin and total white blood cell count) were comparable $(P>0.05)$ across all age brackets except for platelet that significantly $(P<0.05)$ differ across the groups. The extreme age brackets (18-28 years and 49-60 years) had comparable platelet values (same mean subset) while the 29-38 and the 39-48 years age bracket had comparable platelet values (same mean subset).

\section{Discussion}

In this study, we observed significantly $(p<0.05)$ lower glutathione level in the HIV-infected subjects when

Table 4 Antioxidant and some hematological parameters of HIV infected subject on ART and ART naïve subjects

\begin{tabular}{|c|c|c|c|}
\hline \multirow[b]{2}{*}{ Parameter } & \multicolumn{3}{|l|}{ HIV Subjects } \\
\hline & $\begin{array}{l}\text { Subjects on ART } \\
N=60 \\
\text { Mean } \pm \text { S.D }\end{array}$ & $\begin{array}{l}\text { ART naive Subjects } \\
N=40 \\
\text { Mean } \pm \text { S.D }\end{array}$ & $p$-value \\
\hline \multicolumn{4}{|l|}{ ANTIOXIDANTS } \\
\hline $\mathrm{GSH}(\mu \mathrm{g} / \mathrm{mL})$ & $4.32 \pm 2.19$ & $2.93 \pm 0.66$ & $<0.01^{*}$ \\
\hline $\mathrm{GPX}(\mathrm{pg} / \mathrm{mL})$ & $143.22 \pm 71.96$ & $93.04 \pm 19.78$ & $<0.01^{*}$ \\
\hline \multicolumn{4}{|l|}{ HEMATOLOGY } \\
\hline CD4 (cells $/ \mathrm{mm}^{3}$ ) & $442.17 \pm 242.99$ & $342.33 \pm 208.58$ & $<0.01^{*}$ \\
\hline $\mathrm{Hb}(\mathrm{g} / \mathrm{dL})$ & $11.70 \pm 1.99$ & $10.63 \pm 1.37$ & $<0.01^{*}$ \\
\hline WBC $\left(\times 10^{9} / L\right)$ & $4.02 \pm 1.15$ & $3.21 \pm 0.58$ & $<0.01^{*}$ \\
\hline sPlatelet $\left(\times 10^{9} / \mathrm{L}\right)$ & $205.33 \pm 62.90$ & $136.57 \pm 30.06$ & $<0.01^{*}$ \\
\hline
\end{tabular}

$\mathrm{N}$ absolute number; $\mathrm{Hb}$ hemoglobin; $\mathrm{GSH}$ glutathione;

GPX glutathione peroxidase; WBC white blood cells count

$C D$ cluster of differentiation

*: Significantly different compared with the control group. This finding is consistent with previous reports $[11,25,26]$ indicating higher oxidative stress. Multiple mechanisms may contribute to systemic reduction of GSH in HIV infection. It could be due to an increased usage associated with low synthesis, secondary to the decrease in the availability of substrates $[13,25,27]$. It is known that in pathologic conditions, the three amino acid precursors of GSH synthesis (Glutamine, glycine and cysteine) become essential [28]. Secondly, long term production of inflammatory cytokines (such as IL-1, IL-17 and TNF- $\alpha$ ) leads to production of free radicals. In turn, these free radicals are mopped up by free GSH. This cycle of high production of free radicals and their subsequent mopping ends up with glutathione depletion [29]. In addition, HIVinfected individuals have been reported to have increased levels of TGF- $\beta$ in their plasma [30]. Increased TGF- $\beta$ inhibits the production of Glutamine-cysteine ligase catalytic (GCLC) subunit which reduces the production of molecules of GSH. More so, HIV infection on its own may play vital role through the production and release of HIV-TAT (trans-acting transcriptional activator), [31] since TAT blocks transcription of manganese superoxide dismutase [32], an enzyme that helps to prevent oxidative stress and as well markedly decrease the activity of glucose-6-phosphate dehydrogenase, [21, 33] a key enzyme in pathway that maintain GSH in its reduced state. Choi et al., [34] in an animal study demonstrated that TAT decrease the amount of GSH present in mice through modulation of GSH biosynthetic enzymes. More so, Morris et al., [29] postulated that elevated levels of interleukin 1 (IL-1) also promotes depletion of intracellular cysteine, which in turn reduces the production of new GSH molecules considering the fact that cysteine availability is rate limiting for the synthesis of glutathione. The tripeptide glutathione is synthesized in a 2-step process in which cysteine and glutamate are linked by glutamate cysteine ligase to form gamma-glutamylcysteine which in turn, then linked to glycine by glutathione synthase [35]. T - cell function and viability have been reported to be markedly impaired in GSH depleted cells [21]. The glutathione redox system performs a critical role in eliminating oxidative stress in the body of oxidation stress and restores homeostasis. To exert antioxidant role, glutathione (GSH) is converted to oxidized form; Oxidized glutathione (GSSG) by glutathione peroxidase (GPX). GSSG can be converted back to GSH by glutathione reductase (GSR) [29].

This study observed significantly reduced glutathione peroxidase (GPX) in the HIV-infected subjects. This observation is in consonance with earlier reports [19, 36, 37]. However, this finding is at variance with earlier report by Delmas-Beauvieux et al., [38] who reported higher GPX 
Table 5 Antioxidant and some haematological parameters the HIV infected subjects based on CD4 category

\begin{tabular}{|c|c|c|c|}
\hline \multirow[t]{2}{*}{ Parameters } & \multicolumn{2}{|l|}{ CD4 category } & \multirow[t]{2}{*}{$p$-value } \\
\hline & $\begin{array}{l}\text { CD4 <200 cells } / \mathrm{mm}^{3} \\
N=9 \\
\text { Mean } \pm \text { S.D }\end{array}$ & $\begin{array}{l}\text { CD4 } \geq 200 \text { cells } / \mathrm{mm}^{3} \\
N=91 \\
\text { Mean } \pm \text { S.D }\end{array}$ & \\
\hline \multicolumn{4}{|l|}{ ANTIOXIDANTS } \\
\hline $\mathrm{GSH}(\mu \mathrm{g} / \mathrm{mL})$ & $2.57 \pm 0.59$ & $3.88 \pm 1.91$ & $<0.01^{*}$ \\
\hline $\mathrm{GPX}(\mathrm{pg} / \mathrm{mL})$ & $89.57 \pm 20.34$ & $126.47 \pm 63.83$ & $<0.01^{*}$ \\
\hline \multicolumn{4}{|l|}{ HEMATOLOGY } \\
\hline CD4 (cells $/ \mathrm{mm}^{3}$ ) & $131.56 \pm 73.21$ & $442.19 \pm 283.31$ & $<0.01^{*}$ \\
\hline $\mathrm{Hb}(\mathrm{g} / \mathrm{dL})$ & $8.62 \pm 2.22$ & $11.53 \pm 1.58$ & $<0.01^{*}$ \\
\hline WBC $\left(\times 10^{9} / L\right)$ & $2.66 \pm 0.51$ & $3.80 \pm 1.02$ & $<0.01^{*}$ \\
\hline Platelet $\left(\times 10^{9} / \mathrm{L}\right)$ & $102.58 \pm 17.07$ & $185.27 \pm 59.98$ & $<0.01^{*}$ \\
\hline
\end{tabular}

$\mathrm{N}$ absolute number; $\mathrm{Hb}$ hemoglobin; GSH glutathione;

GPX glutathione peroxidase; WBC white blood cells count

$C D$ cluster of differentiation

*: Significantly different

value in the HIV-infected group. We could not "pin point" the reason for this discordance, but we cannot neglect the fact that the subjects used for their study were selenium and vitamin A deficient and had $\mathrm{CD} 4{ }^{+} \mathrm{T}$-cell count less than $0.4 \times 10^{9} / \mathrm{L}$. This protocol may have affected the outcome. GPX plays an important role in the metabolism of reactive oxygen species (ROS) as a defense mechanism against oxidative damage by catalyzing the reduction of a variety of hydroperoxides via glutathione as the reducing substrate. Antioxidant enzyme levels are sensitive to oxidative stress and alterations usually leads to cell damage and weakened antioxidant defense [19].

This study showed that HIV infected subjects on ART had significantly elevated glutathione (GSH) and glutathione peroxidase (GPX) levels. Few studies have examined the effect of ART on oxidative stress parameters and these studies remains conflicting. Just like the result

Table 6 Antioxidant and some haematological parameters the HIV infected subjects based on gender

\begin{tabular}{clll}
\hline Parameters & \multicolumn{2}{l}{ Gender } & p-value \\
\cline { 2 - 3 } & $\begin{array}{l}\text { Male HIV subjects } \\
N=46\end{array}$ & $\begin{array}{l}\text { Female HIV subjects } \\
N=54\end{array}$ & \\
& Mean \pm S.D & Mean \pm S.D & \\
\hline ANTIOXIDANTS & & & \\
GSH $(\mu \mathrm{g} / \mathrm{mL})$ & $3.33 \pm 1.38$ & $4.13 \pm 2.16$ & $0.030^{*}$ \\
GPX $(\mathrm{pg} / \mathrm{mL})$ & $110.45 \pm 50.56$ & $133.96 \pm 69.00$ & 0.053 \\
HEMATOLOGY & & & \\
CD4 (cells $\left./ \mathrm{mm}^{3}\right)$ & $366.24 \pm 207.33$ & $455.11 \pm 253.08$ & 0.060 \\
Hb $(\mathrm{g} / \mathrm{dL})$ & $11.33 \pm 2.19$ & $11.22 \pm 1.50$ & 0.766 \\
WBC $\left(\times 10^{9} / \mathrm{L}\right)$ & $3.41 \pm 0.70$ & $3.94 \pm 1.21$ & $0.009^{*}$ \\
Platelet $\left(\times 10^{9} / \mathrm{L}\right)$ & $166.74 \pm 54.26$ & $187.28 \pm 67.18$ & 0.100
\end{tabular}

$\mathrm{N}$ absolute number; $\mathrm{Hb}$ hemoglobin; $\mathrm{GSH}$ glutathione;

GPX glutathione peroxidase; WBC white blood cells count

$C D$ cluster of differentiation

*: Significantly different of this study, Aukrust and colleagues [15] reported improvement in glutathione redox-status following administration of highly active antiretroviral therapy (HAART), though without full normalization. HAART administration was reported to suppress spontaneous release of TNF- $\alpha$ in PMBC from HIV infected subjects. Glutathione supplementation has been reported to increases cell proliferation in vitro [15]. More so, Sundaram and colleagues [19] reported increase in GPX in HIV infected subjects on ART over time. However, contrary report showed that ART is associated with increased oxidative stress [38].

This study observed significantly reduced glutathione peroxidase in HIV-infected subjects with $\mathrm{CD}^{+}{ }^{+} \mathrm{T}$-cell count $<200$ cells $/ \mathrm{mm}^{3}$. This observation is consistent with earlier report by Herzenberg and colleagues [21] who reported lower GSH in HIV-infected subjects with $\mathrm{CD} 4{ }^{+}$T-cell count of $<200$ cells $/ \mathrm{mm}^{3}$. CD4 count $<200$ cells $/ \mathrm{mm}^{3}$ has been reported to predict decreased survival [21].

We observed significantly lower glutathione level in the HIV-infected males when compared with the females. Previous animal studies have shown sex specific differences in antioxidant capacities in various tissues [39-41]. Lower levels of the $\mathrm{H}_{2} \mathrm{O}_{2}$ and higher levels of GSH and GPX activities have been reported in female mitochondria which is postulated to confer protection from ROS-mediated damage [42, 43].

We observed significantly lower $\mathrm{CD} 4^{+} \mathrm{T}$-cell count in the HIV-infected subjects when compared with the control subjects. This observation is in consonance with previous findings. Depletion of $\mathrm{CD}^{+}{ }^{+} \mathrm{T}$-cell in HIV infection has been well documented [37, 44, 45]. The central event in HIV infection is destruction of $\mathrm{CD} 4^{+} \mathrm{T}$ cells leading to a compromised immune system [46].

This study observed significantly lower hematological parameters in the HIV-infected subjects when compared 
Table 7 Antioxidants and some hematological parameters of HIV infected subjects on ART treatment based on duration of treatment

\begin{tabular}{|c|c|c|c|c|}
\hline \multirow[b]{2}{*}{ Parameter } & \multicolumn{4}{|c|}{ Duration of ART treatment (years) } \\
\hline & $\begin{array}{l}0-4 \\
N=32 \\
\text { Mean } \pm \text { S.D }\end{array}$ & $\begin{array}{l}5-8 \\
N=18 \\
\text { Mean } \pm \text { S.D }\end{array}$ & $\begin{array}{l}9-12 \\
N=10 \\
\text { Mean } \pm \text { S.D }\end{array}$ & $p$-value \\
\hline \multicolumn{5}{|l|}{ ANTIOXIDANTS } \\
\hline $\mathrm{GSH}(\mu \mathrm{g} / \mathrm{mL})$ & $4.60 \pm 2.03$ & $4.62 \pm 2.62$ & $2.82 \pm 1.27$ & 0.731 \\
\hline $\mathrm{GPX}(\mathrm{pg} / \mathrm{mL})$ & $137.21 \pm 63.37$ & $162.72 \pm 91.33$ & $127.37 \pm 56.44$ & 0.374 \\
\hline CD4 (cells/mm³) & $460.06 \pm 247.25$ & $484.44 \pm 227.05$ & $428.80 \pm 277.33$ & 0.851 \\
\hline \multicolumn{5}{|l|}{ HEMATOLOGY } \\
\hline $\mathrm{Hb}(\mathrm{g} / \mathrm{L})$ & $11.69 \pm 1.71$ & $11.73 \pm 2.00$ & $11.68 \pm 2.89$ & 0.482 \\
\hline WBC $\left(\times 10^{9} / \mathrm{L}\right)$ & $3.90 \pm 1.04$ & $4.11 \pm 1.35$ & $4.06 \pm 1.16$ & 0.644 \\
\hline Platelet $\left(\times 10^{9} / \mathrm{L}\right)$ & $194.97 \pm 58.32$ & $211.94 \pm 69.03$ & $226.66 \pm 65.20$ & 0.337 \\
\hline
\end{tabular}

$\mathrm{N}$ absolute number; $\mathrm{Hb}$ hemoglobin; GSH glutathione

GPX glutathione peroxidase; WBC white blood cells count

$C D$ cluster of differentiation

with the control. Hematological indices provide physiological information on the blood picture and the reticuloendothelial system [47]. The hemoglobin, total white blood cell count and platelet count were all significantly lowered in the HIV-infected subjects. This finding is similar to previous reports, $[44,48]$ except in Asemota et al., [44] where the platelet counts were comparable. Anemia prevalence of $74 \%$ was observed in this study using $12 \mathrm{~g} / \mathrm{dL}$ and $13 \mathrm{~g} / \mathrm{dL}$ cutoff for females and males, respectively. This value is similar to $80 \%$ obtained in another study in Nigeria [49]. However, lower values of $56 \%$ [44], 60.1\% [50] and 64.0\% [51] have been reported. The Anemia Prevalence Study Group [52], Women's Interagency HIV study (WIHS) [53] and Human Immunodeficiency Virus Epidemiology Research (HER) [54] reported that HIV-positive patients who were African American demonstrated a higher prevalence in anemia than found in other races. This disparity in anemia prevalence may be due to regional differences. A common cause of anemia among patients living with HIV is blood loss. This might be associated with neoplastic conditions such as Kaposi sarcoma in the gastrointestinal tract or gastrointestinal injury that follow opportunistic cytomegalovirus infection. Apart from blood loss, the pathophysiology of HIV involving anemia may be explained via three fundamental mechanisms which are: elevated red blood cell destruction, reduction in red blood cell production and ineffective red blood cell production [55]. More so, Zidovudin treatment has been reported to induce bone marrow suppression and consequently increase odd of developing anemia [56-58]. Retrospective analysis has shown that baseline anemia is correlated with decreased survival, and increased disease progression in HIV infection [50,51]. Unlike the result of this study, the Anemia Prevalence Study Group [52] reported $71 \%$ greater prevalence of anemia among women than

Table 8 Antioxidant and some hematological parameters of HIV-infected subjects based on age

\begin{tabular}{|c|c|c|c|c|c|}
\hline \multirow[b]{2}{*}{ Parameter } & \multicolumn{5}{|c|}{ Age of HIV-infected subjects (years) } \\
\hline & $\begin{array}{l}18-28 \\
N=21 \\
\text { Mean } \pm \text { S.D }\end{array}$ & $\begin{array}{l}29-38 \\
N=23 \\
\text { Mean } \pm \text { S.D }\end{array}$ & $\begin{array}{l}39-48 \\
N=24 \\
\text { Mean } \pm \text { S.D }\end{array}$ & $\begin{array}{l}49-60 \\
N=32 \\
\text { Mean } \pm \text { S.D }\end{array}$ & $p$-value \\
\hline \multicolumn{6}{|l|}{ ANTIOXIDANTS } \\
\hline $\mathrm{GSH}(\mu \mathrm{g} / \mathrm{mL})$ & $3.99 \pm 1.97$ & $3.78 \pm 1.59$ & $4.28 \pm 2.52$ & $3.22 \pm 1.28$ & 0.189 \\
\hline GPX (pg/mL) & $110.40 \pm 49.51$ & $137.25 \pm 69.91$ & $139.57 \pm 76.54$ & $109.06 \pm 47.24$ & 0.141 \\
\hline CD4 (cells $/ \mathrm{mm}^{3}$ ) & $451.76 \pm 260$ & $488.74 \pm 322.66$ & $340.25 \pm 163.24$ & $395.13 \pm 177.59$ & 0.164 \\
\hline \multicolumn{6}{|l|}{ HEMATOLOGY } \\
\hline $\mathrm{Hb}(\mathrm{g} / \mathrm{dL})$ & $11.80 \pm 1.71$ & $11.01 \pm 2.25$ & $16.46 \pm 1.82$ & $10.97 \pm 1.59$ & 0.352 \\
\hline WBC $\left(\times 10^{9} / \mathrm{L}\right)$ & $3.42 \pm 0.72$ & $3.88 \pm 1.46$ & $3.75 \pm 0.85$ & $3.69 \pm 0.99$ & 0.559 \\
\hline Platelet $\left(\times 10^{9} / \mathrm{L}\right)$ & $170.43 \pm 55.77^{a}$ & $191.50 \pm 70.16^{b}$ & $181.50 \pm 70.16^{b}$ & $166.44 \pm 62.65^{a}$ & $0.040^{*}$ \\
\hline
\end{tabular}

$\mathrm{N}$ absolute number; $\mathrm{Hb}$ hemoglobin; GSH glutathione; *: Significantly different; Means with the same superscript belongs to the same mean group and do not differ significantly from each other GPX glutathione peroxidase; WBC white blood cells count $C D$ cluster of differentiation 
among men in America using cutoff point of $12 \mathrm{~g} / \mathrm{dL}$ and $13 \mathrm{~g} / \mathrm{dL}$ for females and males respectively. However, an earlier study in Nigeria by Omoregie and colleagues [50] reported no significant disparity in anemia among HIV-infected subjects based on gender, but on further stratification, reported significantly higher anemia prevalence among ART naïve males than their female counterpart. We observed that majority of the ART naïve HIV-infected subjects were anemic in relation to HIV infected subjects on ART. This goes further to corroborate earlier submission of the ameliorative effect of ART on anemia status in HIV infection [44]. Further stratification of the HIV-infected subjects on ART based on gender showed that males on ART treatment had significantly higher prevalence of anemia than their female counterpart. This trend may partly explain the reason of the gender disparity on anemia status observed in this study. Males have been reported to have poor adherence to therapy than females. A report from Malawi [59] showed that men have lower compliance to therapy as indicated by their higher loss to follow-up (18.6\% versus $13.0 \%)$. Furthermore, men have been reported to initiate ART late in HIV infection than women. Prevention of mother to child transmission has been proposed as an explanation for early detection and subsequent presentation for ART [60]. More so, we observed higher odds of anemia in HIV infection in those with $\mathrm{CD}^{+}{ }^{+} \mathrm{T}$-cell count $<200$ cells $/ \mathrm{mm}^{3}$. This corroborates the fact that $\mathrm{CD} 4{ }^{+} \mathrm{T}$-cells are protective of the cytotoxic pathology of the HIV infection.

\section{Conclusions}

This study found significant changes in antioxidants such as GSH and GPX which was more critical in the ART naïve HIV-infected subjects. Supplementation with glutathione or antioxidants may improve the condition. Some authors have reported improved survival associated with oral $\mathrm{N}$-acetylcystein (NAC) administration in HIV infection [61, 62].

\footnotetext{
Abbreviations

3TC: Lamivudine; ABC: Abacavir; ART: Antiretroviral therapy; ATV: Atazanavir; AZT: Zidovudine; CD: Cluster of differentiation; DRV: Darunavir;

DTG: Dolutegravir; EFV: Efavirenz; ELISA: Enzyme-linked immunosorbent assay; FTC: Emtricitabine; GCL: Glutathione-cysteine ligase; GPX: Glutathione peroxidase; GSH: Glutathione; GSR: Glutathione reductase; GSS: Glutathione synthase; GSSG: Oxidised glutathione; HIV: Human immunodeficiency virus; HRP: Horseradish peroxidase; IL: Interleukin; INI: Integrase inhibitor; LPV: Iopinavir; NADPH: Nicotinamide adenine dinucleotide phosphate; NF: Nuclear factor; NNRTI: Non-nucleoside reverse transcriptase inhibitor; NRTI: Nucleoside/nucleotide reverse transcriptase inhibitor; NVP: Nevirapin; OR: Odd ratio; PI: Protease inhibitor; r: Ritonavir; RAL: Raltegravir; rGSH: Reduced glutathione; RNA: Ribonucleic acid; TAT: Trans-acting transcriptional activator; TDF: Tenofovir disoproxil fumarate; TMB: Tetramethylbenzydine; WBC: White blood cell; WHO: World health organization
}

Acknowledgements Not applicable.

\section{Authors' contributions}

Conception of study: CSB; Design of study: CSB and EKU; Sample analysis: CSB, EAA and HUO; Data analysis: CSB, EAA, HUO, JEE, EEF, IJI, EKU; Statistical analysis: EAA and HUO; Initial manuscript draft: CSB, EAA and HUO; All authors read and approved the final manuscript.

\section{Funding}

There was no funding for this study.

\section{Availability of data and materials}

Datasets generated and analysed in this study are available from the corresponding author on request.

\section{Ethics approval and consent to participate}

This study was approved by Health Research Ethical Committee (HREC) of the University of Calabar Teaching Hospital. Oral informed consent was obtained from the participants and same was approved by the ethics committee.

\section{Consent for publication}

Not applicable.

\section{Competing interests}

The authors declare that they have no conflict of interest.

\section{Author details}

${ }^{1}$ Haematology Unit, University of Calabar Teaching Hospital, Calabar, Nigeria. ${ }^{2}$ Haematology Unit, Department of Medical Laboratory Science, University of Calabar, Calabar, Nigeria. ${ }^{3}$ Department of Biochemistry, Federal University of Lafia, Nasarawa, Nigeria.

Received: 16 May 2018 Accepted: 15 October 2019

Published online: 08 November 2019

\section{References}

1. World Health Organization (WHO). Global Health Observation (GHO) data: HIV/AIDS available at: www.who.gho/hiv/en. Accessed Apr 14, 2018.

2. Okoroiwu HU, Okafor IM, Asemota EA, Okpokam DC. Seroprevalence of transfusion-transmissible infections ( $\mathrm{HBV}, \mathrm{HCV}$, syphilis and HIV) among prospective blood donors in a tertiary health care facility in Calabar, Nigeria; an eleven years evaluation. BMC Public Health. 2018;18:645.

3. Obiomah CF, Obeagu El, Ochei KC, Swem CA, Amachukwu BO. Hematological indices o HIV seropositive subjects in Nnamdi Azikiwe University teaching hospital (NAUTH), Nnewi. Ann Clin Lab Res. 2018; 6(1):1-4.

4. Nsonwu-Anyanwu AC, Ighodalo EV, King D, Agu CE, Jeremiah S, Solomon OT, Usoro CAO. Biomarkers of oxidative stress in HIV seropositive individuals on highly active antiretroviral therapy. React Oxygen Species. 2017;3(9):1-11.

5. Joint United Nations Programme on HIV and AIDS (UNAIDS). The gap report: Children and pregnant women living with HIV. Geneva: UNAIDS; 2014.

6. Joint United Nations Programme on HIV and AIDS (UNAIDS). Country fact sheets; Nigeria. 2017. Available at: www.unaids.org/en/regionscountries/ nigeria. Accessed 29 Sept 2018

7. Joint United Nations Programme on HIV and AIDS (UNAIDS). Country fact sheets; South Africa. 2017. Available at: www.unaids.org/en/ regionscountries/southafrica. Accessed 29 Sept 2018.

8. Awofala AA, Ogundele OE. HIV epidemiology in Nigeria. Saudi J Biol Res. 2018;25(4):697-703.

9. Federal Ministry of Health. National guidelines for HIV prevention, treatment and care. National AIDS and STIs control Programme. Abuja: Federal Ministry of Health; 2016. Pp 1-218.

10. Watanabe LM, Barbosa F, Jordao AA, Navarro AM. Influence of HIV infection and the use of antiretroviral therapy on selenium and selenomethionine concentrations and antioxidants protection. Nutrition. 2016;32(1):38-1242.

11. World Health Organization. HIV/AIDS; Summary of new recommendations (Consolidated ARV guidelines, June 2013. Available at: https://www.who.int/hiv/pub/guidelines/arv2013/intro/rag/en/index4. html. Accessed Sept 7, 2019. 
12. Zhao L, Cox AG, Ruzicka JA, Bhat AA, Zhang W, Taylor EW. Molecular modeling and in vitro activity of HIV-1-encoded glutathione peroxidase. Proc Natl Acad. 2000;97:6356-61.

13. Stephensen CB, Marquis GS, Douglas SD, Wilson CM. Immune activation and oxidation damage in HIV-positive and HIV-negative adolescents. J Acquir Immune Defic Syndr. 2005;38:180-90.

14. Steinbrenner H, Al-Quraishy S, Dkhil MA, Wunderlich F, Helmut S. Dietary selenium in adjuvant therapy of viral and bacterial infections. Adv Nutr. 2015;6:73-82.

15. Aukrust P, Miller F, Svardal AM, Ueland T, Berge RK, Freland SS. Disturbed glutathione metabolism and decreased antioxidant levels in human immunodeficiency virus-infected patients during highly active retroviral therapy-potential immunomodulatory effects of antioxidants. J Infect Dis. 2003; 188:232-8

16. Halliwell B. Antioxidant defence mechanisms: from the beginning to the end (of the beginning). Free Radic Res. 1999;31:261-72.

17. Hensley K, Robinson KA, Gabbita SP, Salsman S, Floyd RA. Reactive oxygen species, cell signaling and cell injury. Free Radic Biol Med. 2000;28:1456-62.

18. Orem A, Yandi Y, Vanizor B, Cimsit G, Uydu HA, Malkoc M. The evaluation of the autoantibodies against oxidatively modified low density lipoprotein (LDL), susceptibility of LDL to oxidation, serum lipids and lipid hydroperoxidase levels, total antioxidant status, antioxidant enzyme activities, and endothelial dysfunction in patients with Behcet's disease. Clin Biochem. 2002;35:217-24

19. Sundaram M, Saghayam S, Priya B, Venkatesh KK, Balakrishnan P, Shankar EM, et al. Changes in antioxidant profile among HIV-infected individuals on generic highly active antiretroviral therapy in southern India. I I Infect Dis. 2008;12:e61-6.

20. Cribs SK, Guidof DM, Martin GS, Lenox J, Brown LA. Anti-retroviral therapy is associated with decreased alveolar glutathione levels even in healthy HIVinfected individuals. PLoS One. 2014;9(2):e88630.

21. Herzenberg LA, De Rosa SC, Dubs JG, Roederer M, Anderson MT, Ela SW, et al. Glutathione deficiency is associated with impaired survival in HIV disease. Proc Natl Acad Sci U S A. 1997;9:1967-72.

22. Saing $T$, Lagman M, Castrillion J, Gitierrez E, Guilford F, Venketaraman V. Analysis of glutathione level in the brain tissue samples from HIV-1 positive individuals and subjects with Alzheimer's disease and its implication in the pathophysiology of the disease processes. BBA Clin. 2016;6:38-44

23. Staal FJ. Glutathione and HIV-1 infection: reduced or increased oxidized. Eur J Clin Investig. 1998;28(3):194-6.

24. World Health Organization (WHO). Hemoglobin concentration for the diagnosis of anemia and assessment of severity. Vitamin and Mineral Nutritional Information System. Geneva: WHO; 2011 (WHO/NMH/NHD/ MNM/11.1). Pp 1-6. Available at: http://www.who.int/vmnis/indicators/ haemoglobin.pdf. Accessed 29 Sept 2018.

25. Jahoor F, Jackson A, Gazzard B, Philips G, Sharpstone D, Frazer ME, et al. Erythrocyte glutathione deficiency in symptom-free HIV infection is associated with decreased synthesis rate. Am J Physiol Endocrinol Metab. 1999;276:E205-11.

26. de Quay B, Malinverni R, Lauterburg BH. Glutathione depletion in HIVinfected patients: role of cystein deficiency and effect of oral Nacetylcystein. AIDS. 1992;6:815-9.

27. Borges-Santos MD, Moreto F, Pereira CM, Ming-Yu Y, Burini RC. Plasma glutathione of HIV patients responded positively and differently to dietary supplementation with cysteine or glutamine. Nutrition. 2012;28:753-6.

28. Grimble RF. Immunonutrition. Curr Opin Gastroenterol. 2005;21:216-22.

29. Morris D, Guerra C, Donohue C, Oh H, Khurasany M, Venketaraman V. Unveiling the mechanisms for decreased glutathione in individuals with HIV infection. Clin Dev Immunol 2012; 734125. dio:https://doi.org/10.1155/2012/ 734125

30. Moris D, Ly J, Chi P, Daliva J, Nguyen T, Soofer C, et al. Glutathione synthetic is compromised in erythrocytes from individuals with HIV. Front Pharmacol. 2014:5:1-6.

31. Ehret A, Westendorp MO, Herr I, Debatin KM, Heeny JL, Frank R, et al. Resistance of chimpanzee T cells to human immunodeficiency virus type 1 tat-enhanced oxidative stress and apoptosis. J Virol. 1996;70:6502-7.

32. Flores SC, Marecki JC, Harper KP, Bose SK, Nelson SK, McCord JM. Tat protein of human immunodeficiency virus type 1 represses expression of manganese superoxide dismutase in Hela cells. Proc Natl Acad Sci U S A. 1993;90(16):7632-6.
33. Flores S, McCord J. Oxyradicals in medical biology: in advances in molecular and cell biology. Bittar EE, McCord J. (eds). Vol 25. London: JAI Press Inc; 1998.

34. Choi J, Liu RM, Kundu RK, Sangiorgi F, Wu W, Maxson R, et al. Molecular mechanism of decreased glutathione content in human immunodeficiency virus type 1 tat-transgenic mice. J Biol Chem. 2000;275:3693-8.

35. McCarty MF, O'Keefe JH, DiNicolantonio JJ. Dietary Glycine is rate-limiting for glutathione synthesis and may have broad potential for health protection. Ochsner J. 2018;18(1):81-7.

36. Trotti R, Rondanelli M, Anesi A, Gabanti E, Brustia R, Minoli L. Increased erythrocyte glutathione peroxidase activity and serum tumor necrosis factor-a in HIV-infected patients: relationship to on-going prothrombotic state. J Hemother Stem Cell Res. 2002;11(2):369-75.

37. Pasupathi PP, Ramachandran T, Sindhu PJ, Saravanan G. Bakthavathsalam. Enhanced oxidative stress markers and antioxidant imbalance in HIV infection and AIDS patients. J Sci Res. 2009;1(2):370-80.

38. Delmas-Beauvieux M, Peuchant E, Couchouron A, Constans J, Sergeant C, Simonoff $\mathrm{M}$, et al. The enzymatic antioxidant system in blood and glutathione status in human immunodeficiency virus (HIV)-infected patients: effects of supplementation with selenium or $\beta$-carotene. Am J Clin Nutr. 1996:64:101-7.

39. Banos G, Medina-Campos ON, Maldonado PD, Zamora J, Perez I, Pavon N, et al. Antioxidant enzymes in hytertensive and hypertriglyceridemic rat: effects of gender. Clin Exp Hypertens. 2005;27:45-57.

40. Barp J, Araujo AS, Fernandes TR, Rigatto KV, Llesuy S, Bello-Klein A, et al. Myocardial antioxidant and oxidative stress change due to sex hormones. Braz J Med Biol Res. 2002;35(9):1075-81.

41. Katalinic V, Modun D, Music I, Boban M. Gender differences in antioxidant capacity of rat tissues determined by 2,2 - azinobis (3-ethyl-benzothiazoline 6-sulfate ; ABIS) and ferric reducing antioxidant power (FRAP) assays. Comp Biochem Physiol C Toxicol Pharmacol. 2005;140:47-52.

42. Borras C, Sastre J, Garcia-Sala D, Lloret A, Pallador FV, Vina J. Mitochondria from females exhibit higher antioxidant gene expression and lower oxidative damage than males. Free Radic Biol Med. 2003;34:546-52.

43. Jang YM, Kendaiah S, Drew B, Philips T, Selma C, Julian D, Leeuwenburg C. Doxorubicin treatment in vivo activates capase-12 mediated cardiac apoptosis in both male and female rats. FEBS Lett. 2004;577:483-90.

44. Asemota EA, Okafor IM, Okoroiwu HU, Ekong ER, Anyanwu SO, Efiong EE, et al. Zinc, copper, CD4 T-cell count and some hematological parameters of HIV infected subjects in southern Nigeria. Integr Med Res. 2018;7(1):53-60.

45. Nsonwu-Ayanwu AC, Egbe ER, Agu CE, Offor SJ, Usoro CA, Essien IA, et al. Nutritional indices and cardiovascular risk factors in HIV infections in southern Nigeria. J Immunol Microbiol. 2017;2:34-42.

46. Valdivia A, Ly J, Gonzalez L, Hussain P, Saing T, Islamoglu H, et al. Restoring cytokine balance in HIV-positive individuals with low CD4 T-cell count. AIDS Res Hum Retrovir. 2017:33(9):905-18.

47. Okoroiwu HU, Okafor IM, Uko EK, Atangwho IJ. Some hematological parameters of wistar rats treated with chromolaena odorata leave extracts. J Biol Res. 2017;90:51-5.

48. Ositadinma IM, Odozi EB, Meludu SC, Okeke CO. Effects of HIV infection on some hematological parameter and immunoglobulin levels in HIV patients in Benin City, Nigeria, Tanzan. J Health Res. 2009:11:1-4.

49. Erhabor O, Ejele OA, Nwauche CA, Buseri FI. Some hematological parameters in human immunodeficiency virus (HIV) infected Africans: the Nigerian perspective. Niger J Med. 2005;14:33-8.

50. Omoregie R, Omokaro EU, Palmer O, Ogefere HO, Egbeobauwaye A, Adegue JE, et al. Prevalence of anemia among HIV-infected patients in Benin City, Nigeria Tanzan. J Health Res. 2009;11:1-4.

51. Pennap GR, Abubakar K. Prevalence of anemia among human immunodeficiency virus infected patients accessing healthcare in Federal Medical Centre Keffi, Nigeria. Int J Tro Dis Health. 2015;10:1-7.

52. Creagh T, Mildvan D. Greater prevalence of anemia in women and African Americans with HIV/AIDS in HAART era: a study of 10,000 patients (abstract 475). In: The anemia prevalence study group, programme and abstracts of the 40th annual meeting of the Infections Disease Society of America (Chicago), vol. 127. Alexandria: VA Infections Disease Society of America; 2002.

53. Levine AM, Berhane K, Masri-Lavine L, et al. Prevalence and correlate of anemia in a large cohort of HIV infected women: Women's interagency of HIV study. J Aquir Immune Defic Syndr. 2001;26:28-35. 
54. Semba RD, Shah N, Klein RS, et al. Prevalence and cumulative incidence of and risk factors for anemia in a multicentre cohort study of immunodeficiency virus-infected and uninfected women. Clin Infect Dis. 2002;34:260-6.

55. Voilberding PA, Levine AM, Dieterich D, Mildvan D, Mitsuyasu R. Anemia in HIV infection: clinical impact and evidence-based management strategies. Clin Infect Dis. 2004;30(10):1454-63.

56. Fischl M, Galpin JE, Levine JD, et al. Recombinant human erythropoietin for patients with AIDS treated with Zidovudin. N Engl J Med. 1990;322:1488-93.

57. Walker RE, Parker Rl, Kovacs JA, et al. Anemia and erythropoiesis and patients with acquired immunodeficiency syndrome (AIDS) and Kaposi sarcoma treated with zidovudin. Ann Intern Med. 1988;108:372-6.

58. Falguera M, Perez-Mur J, Puig T, Cao G. Study of the role of vitamin B12 and folinic supplementation in preventing hematologic toxicity of zidovudin. Eur J Haematol. 1995:55:97-102.

59. Chen SC, Yu JK, Harries AD, et al. Increased mortality of male adults with AIDS related to poor compliance to antiretroviral therapy in Malawi. Tropical Med Int Health. 2008;13:513-9.

60. Taylor-Smith K, Tweya H, Harries A, Schoutene E, Jahn A. Gender difference in retention and survival on antiretroviral therapy of HIV-1 infected adults in Malawi. Malawi Med J. 2010;22(2):49-56.

61. De Rossa SC, Zaretsky MD, Dubs JG, Roedera M, Anderson M, Green A. Nacetylcysteine replenishes glutathione in HIV infection. Eur J Clin Investig. 2000;30(10):915-25.

62. Atkuri KR, Mantovani JJ, Herzenberg LA, Herzenberg LA. N-acetylcysteine - a safe antidote for cysteine/ glutathione deficiency. Curr Opin Pharmacol. 2007;7(4):355-9.

\section{Publisher's Note}

Springer Nature remains neutral with regard to jurisdictional claims in published maps and institutional affiliations.

Ready to submit your research? Choose BMC and benefit from:

- fast, convenient online submission

- thorough peer review by experienced researchers in your field

- rapid publication on acceptance

- support for research data, including large and complex data types

- gold Open Access which fosters wider collaboration and increased citations

- maximum visibility for your research: over $100 \mathrm{M}$ website views per year

At $\mathrm{BMC}$, research is always in progress.

Learn more biomedcentral.com/submissions 